\title{
生体肝移植後の薬物動態に影響を及ぼす因子に関する研究
}

\author{
村木 優一
}

\section{Factors Affecting the Pharmacokinetics after Living Donor Liver Transplant}

\author{
Yuichi Muraki \\ Department of Pharmacy, Mie University Hospital; 2-174 Edobashi, Tsu, Mie 514-8507, Japan.
}

(Received May 21, 2012)

\begin{abstract}
Fifty-five thousand organ transplants are performed each year around the world. It is now estimated that over 300000 organ transplant recipients are alive worldwide. Most of these transplant recipients will remain on immunosuppressive drugs for the remainder of their lives to prevent rejection episodes. Doses of these medications must be judiciously managed to optimize patient outcomes. Subtherapeutic drug concentrations may lead to graft rejection and subsequent graft loss. Supratherapeutic drug concentrations increase the likelihood of drug toxicities and increase the likelihood of opportunistic infections. In this review, the latest reports concerning the factors affecting the pharmacokinetics of tacrolimus and micafungin after living donor liver transplant (LDLT) are summarized. Our experimental results demonstrate that preoperative assessment of cytochrome P450 3A5 (CYP3A5) genotypes in both recipients and donors and an immune cell function assay would be useful not only for predicting tacrolimus pharmacokinetics but also for defining groups at high-risk of infectious complications after LDLT. Finally, monitoring plasma trough micafungin concentrations allows safe and effective dose titration of micafungin in LDLT-recipients with total bilirubin concentrations greater than $5 \mathrm{mg} / \mathrm{dL}$.
\end{abstract}

Key words — tacrolimus; micafungin; living donor liver transplantation; single nucleotide polymorphism; bilirubin; cytochrome P450 3A5

\section{1.はじめに}

臓器移植は 20 世紀に始まった比較的歴史の浅い 医療であるが，現在では世界中で年間に55000 例が 実施され, 生存している移植患者数は 300000 人以 上と推定されている. 移植医療が急速に進歩した原 因の 1 つに 1980 年代にシクロスポリン, 1990 年代 にタクロリムスが免疫抑制薬として普及したことが 挙げられ，移植成績は飛躍的に向上した。しかしな がら, これらの薬剂は治療域が狭く, 臨床効果を判 定する指標も少ないことから, 重篤な副作用や致死 的な感染症等の合併症を発症する患者も少なからず 存在している. そのため, 患者個々の臨床症状に適 した個別化投与計画の実施が望まれているが，臓器 移植を受けた特殊な病態にある患者の薬物動態に関

The author declares no conflict of interest.

三重大学医学部附属病院薬剂部（T514-8507 三重県津 市江戸橋二丁目 174 番地）

e-mail: y-muraki@clin.medic.mie-u.ac.jp

本総説は, 平成 23 年度日本薬学会東海支部学術奨励賞

の受賞を記念して記述したものである.
する情報はそしい。 さらに，わが国で大部分を占め る生体肝移植は, 薬物代謝を担う肝臓を部分的に移 植しているため, 薬物動態に及ぼす影響も大きいこ とが懸念される.

薬物に対する反応性に個人差が存在することは既 知の事実であるが，その要因として薬物代謝酵素や 薬物トランスポーターの遺伝子多型の関与が多くの 薬物で徐々に明らかにされてきている，移植患者に 共通して使用されるカルシニューリン阻害薬や免疫 抑制に伴う感染症の予防・治療薬には, チトクロム P450 (Cytochrome P450, 以下 CYP) や, 薬物卜 ランスポーターの影響を受けることが多いため, 薬 物間相互作用など臨床上問題となることが多い。こ れらの薬物治療の失敗は患者の死だけでなく, 膨大 な医療資源や貴重な提供臓器を無益のものとするた め, 薬剤師は，チーム医療の中で他職種と連携よく 機能し, 専門性を十分に発揮することが求められて いる. 本稿では生体肝移植後という特殊な病態にあ る患者におけるカルシニューリン阻害薬のタクロリ 
ムスとキャンディン系抗真菌薬のミカファンギンの 薬物動態に変動を及ぼす因子に関してこれまで明ら かにされている知見を含めて，筆者らの結果と併せ て報告する。

\section{2. タクロリムスの薬物動態に対する CYP3A5} の遺伝子多型の影響

臟器移植の免疫抑制療法に使用されるカルシニ ユーリン阻害薬のタクロリムスは，治療域が狭く， 個体間あるいは個体内変動が大きいため，経験的な 投与計画を確立することが困難である.1 ${ }^{1)}$ その原因 として腸管吸収や肝代謝における $\mathrm{P}$ 糖タンパク質 やCYP3A 酵素（主に $3 \mathrm{~A} 4$ や 3A5）の関与が考え られている. 2,3$)$

近年, CYP3A5 に一塩基多型（SNP）が存在し, *1アリルの保有がタクロリムスの代謝を促進する ため，薬物動態に影響を及ぼすことが多数の施設か ら報告されている。 ${ }^{4-9)}$ Haufroid らは，腎移植患者 の実証研究においてタクロリムスの時間曲線下面積 やトラフ值が，投与量が同等であるにもかかわらず $\mathrm{CYP} 3 \mathrm{~A} 5 * 3 / * 3$ の「機能欠損型」では CYP3A $5 * 1 /$ $*_{1}^{*}$ 又は* $1 /{ }^{*} 3$ の「機能発現型」に比べて 2.5 倍程 度高值であることを証明し，10)この結果に基づいた 多施設共同ランダム化比較試験では「機能発現型」 に対して $0.3 \mathrm{mg} / \mathrm{kg}$ ，「機能欠損型」に対して 0.15 $\mathrm{mg} / \mathrm{kg}$ でタクロリムス投与を開始したところ，速 やかに目標血中濃度に到達することができたことが 報告されている. ${ }^{11)}$

一方，これまでに生体肝移植では小腸(患者自身) の CYP3A5 遺伝子多型が移植肝（ドナー）の遺伝 子多型と同様に経口投与されたタクロリムスの初回 通過効果において重要な役割を果たしていることが 報告されている. ${ }^{12,13)}$ 筆者らの施設においても生体 肝移植患者において小腸（患者自身），移植肝（ド ナー）のCYP3A5 遺伝子多型を調へ，術後 12 力月 までの血中濃度及びクリアランスの指標として血中 濃度/投与量 $(\mathrm{C} / \mathrm{D})$ 比を算出し, 経時的に比較し た. ${ }^{14)}$ 血中濃度は調査期間中にいずれも差を認めな かったが，小腸（患者自身）と移植肝（ドナー）の 両方が「機能発現型」である場合に最も低值となり,

「機能発現型」の患者における代謝の促進が認めら れた。 また，その影響は術後 4 週までは小腸（患者 自身）の寄与が大きく，徐々に移植肝（ドナー）の 影響を受けることが推察された（Table 1)。日本人
における「機能発現型」の割合は 39.5-44.2\% と低 $\left.<,{ }^{12}\right)$ 小腸（患者自身）と移植肝（ドナー）の両方 が「機能発現型」の組合せは非常に稀であるため,

今後，多施設共同での検討が望まれる.

\section{CYP3A5 遺伝子多型が臨床効果や副作用に及}

\section{ぼす影響}

免疫抑制療法を困難にしている問題点の 1 つとし て患者の免疫状態を評価する指標の欠如が挙げられ る。そのような中， 2002 年に米国食品医薬品局 （FDA）は末梢血液中の CD4 陽性 T 細胞の機能活 性を測定する ImmuKnow assay (Cylex, Columbia, MD）を認可した。本法は刺激を受けた CD4 陽性 $\mathrm{T}$ 細胞が産生するアデノシン三リン酸（ATP）の 濃度を測定することにより，細胞性免疫能を評価す ることが可能である. ${ }^{15)}$ Kowalski らによる 504 人の 臓器移植患者（肝移植 150 人）のメ夕解析において ImmuKnow assay は感染症や拒絶反応の相対リス クを評価するのに有用としており，免疫反応の指標 として 3 つの区域を確立した（low：ATP 活性值が $225 \mathrm{ng} / \mathrm{mL}$ 以下, moderate：ATP 活性值が 226$524 \mathrm{ng} / \mathrm{mL}$, strong : ATP 活性值が $525 \mathrm{ng} / \mathrm{mL}$ 以 上). ${ }^{16)}$

筆者らは ATP 活性を測定した 40 名の生体肝移 植患者を測定值に基づき上記の 3 群に分類したとこ ろ, low 群では 6/13 例に感染症や C 型肝炎の再燃 を認め, strong 群では $1 / 3$ 例に拒絶反応を認め, 2/ 3 例は B 型肝炎のワクチン接種が実施されていた. Moderate 群では 24 例中 1 例の夕拒絶反応を認めて おり，Kowalski らの結果を支持するものであっ た。一方，これら 3 群間のタクロリムス血中濃度に 有意な差は認められず， low 群では半数（3/6 例） が CYP $3 \mathrm{~A} 55^{*} 1 /{ }^{*} 1$ 又は* $1 /{ }^{*} 3$ の「機能発現型」であ り, strong 群はすべて CYP3A5*3/*3 の「機能欠損 型」であつた (Fig. 1). 17)

タクロリムスの薬物動態に CYP3A5 遺伝子多型

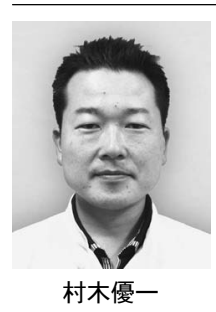

1976 年生まれ. 1999 年京都薬科大学薬 学部, 2001 年同大学院修士課程卒業 後, 三重大学病院薬剤部勤務, 2005 年 薬剂主任，2009 年助教，2010 年三重大 学大学院医学系研究科博士課程修了. 現在は移植医療, 感染症治療, 感染制 御での活動を中心とした研究に取り組 み，医療薬学への貢献を目標にしてい る. 
Table 1. Tacrolimus Concentration/Dosage Ratio for Different Combination of CYP3A5 Genotypes for Both Recipients (Intestine) and Donors (Liver) until 12 months Post-transplantation

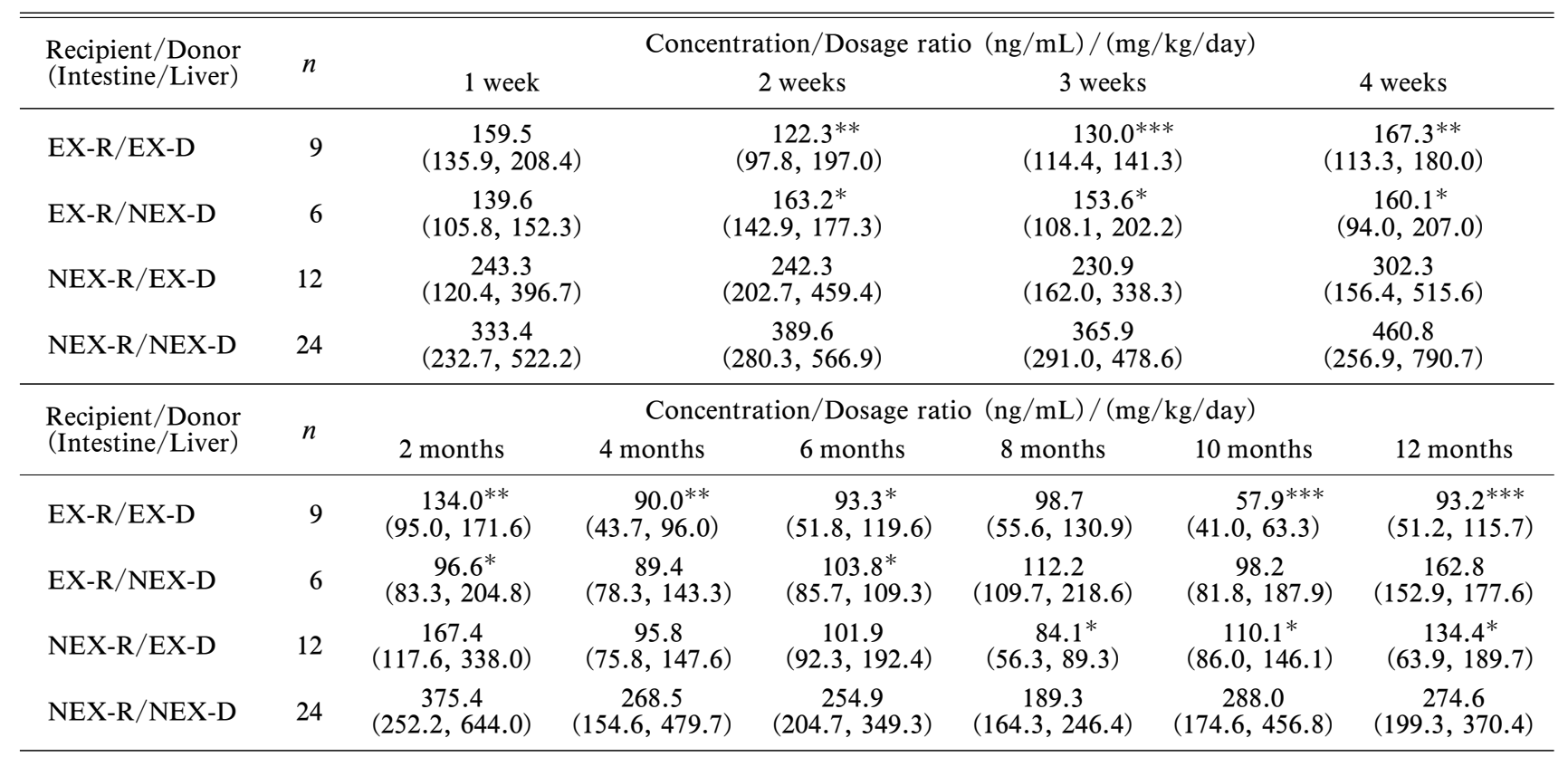

Values presented are medians (25 percentile, 75 percentile) ${ }^{*} p<0.05,{ }^{* *} p<0.01,{ }^{* * *} p<0.001$ ( $v s$. NEX-R/NEX-D) . EX: expressor $\left({ }^{*} 1 /{ }^{*} 1\right.$ or $\left.{ }^{*} 1 /{ }^{*} 3\right)$, NEX: non-expressor $(* 3 / * 3)$. Patients with no available tacrolimus levels at the time were excluded. The details are in ref. 14).

a)

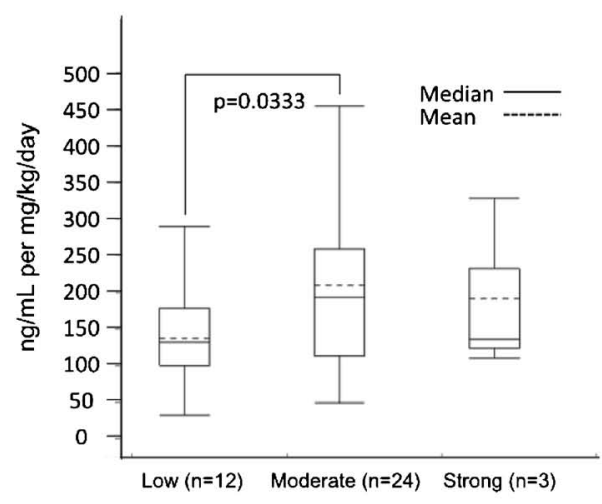

b)

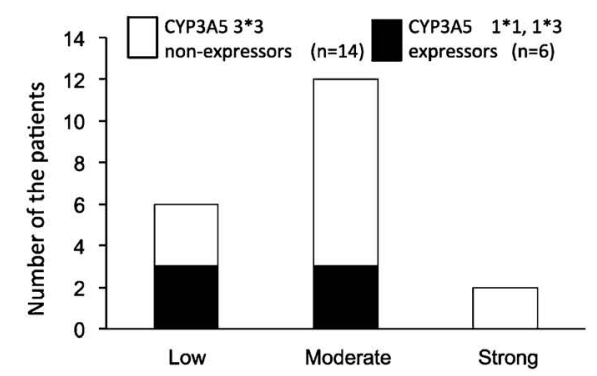

Fig. 1. Relationship between ImmuKnow ATP Results and Tacrolimus Concentration/Dose (C/D) Ratio or CYP3A5 Genotype

a): Tacrolimus concentration/dosage (C/D) ratio in each group. The mean tacrolimus C/D ratio was $124.2 \mathrm{ng} / \mathrm{mL} \mathrm{per} \mathrm{mg/kg/day} \mathrm{(33.4-251.4)} \mathrm{in} \mathrm{low} \mathrm{group,}$ 209.4 (50.3-454.1) in moderate group, and 191.6 (98.7-327.2) in strong group, respectively. There was significant difference between group A and group B ( $p=$ $0.0333)$. b) : Correlation of ImmuKnow ATP results with CYP3A5 genotype. The CYP3A5 genotype, ${ }^{*} 1 /{ }^{*} 1$ or $* 1 /{ }^{*} 3$ alleles (expressors) were found in six patients $(30 \%)$ and ${ }^{*} 3 /{ }^{*} 3$ alleles (non-expressors) were in 14 patients $(70 \%)$. Although patients with ${ }^{*} 1 /{ }^{*} 1$ or ${ }^{*} 1 /{ }^{*} 3$ alleles (expressors) were three out of six (50\%) in low group and three out of $12(25 \%)$ in moderate group, none in strong group. The details are in ref. 17).

が影響することは多数報告されているが，CYP3A5 遺伝子多型が副作用やグラフト生存率などの治療成 績に及ぼす影響に関する情報は少ない。これまでに CYP3A5 遺伝子多型が中間代謝物を蓄積させるた め腎毒性に関与するといった報告18)や腎臓の CYP3A5 が腎毒性の保護的役割を担うといつた報 告があり, ${ }^{19)}$ 一定の見解が得られていない。われわ れの別の研究では臨床効果の指標として感染症, 拒
絶反応, 副作用発現の有無を確認し, CYP3A5 遺 伝子多型の影響をロジスティック回帰分析により評 価した. ${ }^{14)}$ 小腸（患者自身）と移植肝（ドナー）と もに CYP $3 A 5^{*} 1 /{ }^{*} 1$ 又は* $1 /{ }^{*} 3$ の「機能発現型」で ある場合，感染症の合併率は $85.7 \%(6 / 7$ 例） と CYP3A5*3/*3 の「機能欠損型」の約 2 倍であり, そのオッズ比は $8.67(p=0.0309)$ であった（Table 2). 
Table 2. The Impact on CYP3A5 Genotype on Infectious Complication Using Logistic Regression Analysis

\begin{tabular}{ccc}
\hline \hline \multicolumn{1}{c}{ Parameters } & $\begin{array}{c}\text { Odds Ratio } \\
(95 \% \text { Confidence interval })\end{array}$ & $\begin{array}{c}p \\
\text { value }\end{array}$ \\
\hline $\begin{array}{c}\text { Infectious complication } \\
\text { EX-R/EX-D } \\
\text { (recipient/donor) }\end{array}$ & $8.67(1.20-178.90)$ & 0.0309 \\
$\begin{array}{l}\text { EX-R/NEX-D } \\
\text { (recipient/donor) }\end{array}$ & $1.44(0.22-9.46)$ & 0.6911 \\
$\begin{array}{l}\text { NEX-R/EX-D } \\
\text { (recipient/donor) }\end{array}$ & $1.20(0.22-9.46)$ & 0.8036 \\
$\begin{array}{l}\text { NEX-R/NEX-D } \\
\text { (recipient/donor) }\end{array}$ & - & \\
\hline
\end{tabular}

EX: expressor $\left(* 1 /{ }^{*} 1\right.$ or $\left.{ }^{*} 1 /{ }^{*} 3\right)$, NEX: non-expressor $\left(* 3 /{ }^{*} 3\right)$. Four groups divided recipient or donor genotype as confounding factor were submitted to multivariate analysis using a logistic regression model. The details are in ref. 14).

生体肝移植後の CYP $3 A 5^{*} 1 /{ }^{*} 1$ 又は**1/*3 の「機 能発現型」患者において胆汁中にタクロリムスの微 量代謝物（M-II）が高濃度で認められた症例報告 もあることから, ${ }^{20)} \mathrm{CYP} 3 \mathrm{~A} 5 * 1 /{ }^{*} 1$ 又は* $1 / * 3$ の 「機能発現型」の患者では代謝物の蓄積により過度 の免疫抑制が起こり, 結果として感染症を引き起こ す可能性が推察された，今後，遺伝子多型情報に基 づいた前向きな免疫抑制薬の投与計画を実施し, ImmuKnow assay を利用した免疫抑制効果の評価 を実施することで，さらなるテーラーメイド医療の 実現につながるものと考えている.

\section{4. 生体肝移植患者におけるミカファンギンの臨} 床効果

臓器あるいは骨髄移植における真菌感染症の発症 率は，細菌あるいはウイルス感染症と比較して低い が致死率は高い. ${ }^{21)}$ 肝臟移植における原因真菌は, 77-83\%が Candida 属であり，20-23\%が Aspergillus 属と報告されている. ${ }^{22)}$ キャンディン系抗真菌 薬であるミカファンギンは, ヒトにはない細胞壁を 阻害し, 従来の抗真菌薬と異なる作用機序を有して いることから安全性が高く, ${ }^{23,24)}$ Candida 属や Aspergillus 属に対しても良好な抗真菌活性を有す ることから移植領域における真菌予防あるいは治療 に広く用いられている. ${ }^{25-29)}$

筆者らの施設において真菌感染症の指標である $\beta$-D-グルカンの上昇や臨床症状によりミカファンギ ンを投与した 20 名の生体肝移植患者に対して薬物 治療モニタリングを実施し，臨床効果及び副作用を 調査した. ${ }^{30)}$ いずれの患者においても，臨床症状の
改善により投与が中止され， $\beta$-D-グルカンは有意な 低下を認めた $(p<0.0001)$ ，それらの患者における 投与前のミカファンギン濃度は $4.6 \pm 2.1 \mu \mathrm{g} / \mathrm{mL}$ （平均土標準偏差）であり，投与量は $147.9 \pm 10.2$ $\mathrm{mg} /$ day（平均土標準偏差）であった。 また，投与 中患者に副作用は認められなかった。下枝らは血液 疾患患者におけるアスペルギルスの治療に対してミ カファンギンの目標卜ラフ濃度を $5 \mu \mathrm{g} / \mathrm{mL}$ 以上に することを推奨している. ${ }^{27)}$ 一方，岸野らは予防投

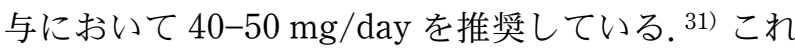
らの結果から, 真菌感染の治療目的にてミカファン ギンを使用する場合，生体肝移植患者においても $150 \mathrm{mg} /$ day で投与することにより安全で有効な治 療濃度が得られることが考えられる。

\section{5. ミカファンギンの薬物動態に対するビリルビ ンの影響}

ミカファンギンは血漿タンパク結合率が $99.5 \%$ 以上と高く，ミカファンギンとその代謝物の $90 \%$ が胆汁から排泄される. ${ }^{32)}$ これまでに，ミカファン ギンは健常人において 2.5-150 mg/day の容認性を 認め, ${ }^{33)}$ 高齢者又は重度腎機能障害患者や中等度肝 機能障害患者においても投与量の調節が不要である ことが報告されている. ${ }^{32,34)}$ また，血漿中濃度曲線 下面積や最高血漿中濃度などの薬物動態パラメー夕 は，健常成人や小览患者において投与量と比例する ことが報告されている. ${ }^{24,35)}$ 筆者らの結果において もミカファンギンの最高血漿濃度と最小血漿中濃度 及び投与量と最小血中濃度の間には有意な相関を示 したことから，生体肝移植患者においても同様の結 果が得られることが示唆された [Figs. $2(\mathrm{~A})$ and (B) ]. ${ }^{30)}$

これまでにミカファンギンの体内動態に影響を及 ぼす因子として血液疾患患者における高ビリルビン 血症が報告されている. ${ }^{36)}$ 筆者らも血漿中濃度測定 時の各種臨床検査值と最小血漿中濃度あるいはクリ アランスの指標となる血漿中濃度/投与量 $(\mathrm{C} / \mathrm{D})$ 比を算出し，相関性を調査した結果，総ビリルビン 值と有意な相関が認められた [Figs. 2(C) and 3 (A) ].また，これらの相関は二相性を示していた ため，中等度高ビリルビン血症の指標となる $5 \mathrm{mg} /$ $\mathrm{dL}$ で 2 群に分類し， C/D 比を比較したところ 5 $\mathrm{mg} / \mathrm{dL}$ よりも大きい群では $5 \mathrm{mg} / \mathrm{dL}$ 以下の群より も有意に高值であり，正の相関を示す傾向が認めら 

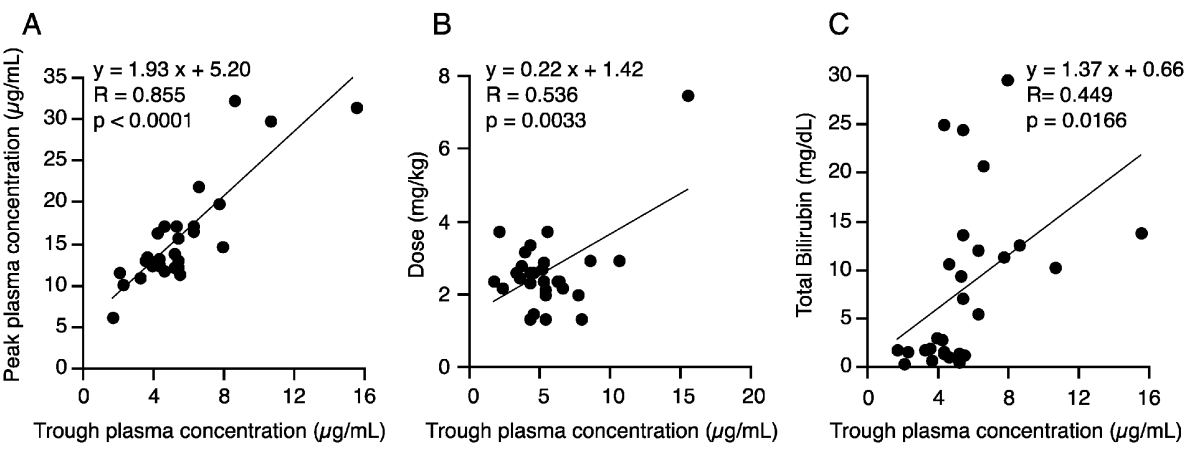

Fig. 2. The Relationships between the Trough Plasma Concentration of MCFG and Dose (A), Peak Plasma Concentration (B) and Total Bilirubin Level (C) in LDLT-recipients

$N=19, n=28$. $N=$ number of patients, $n=$ number of cases. Patients with no available bilirubin levels at the time of administration were excluded. The details are in ref. 30 ).
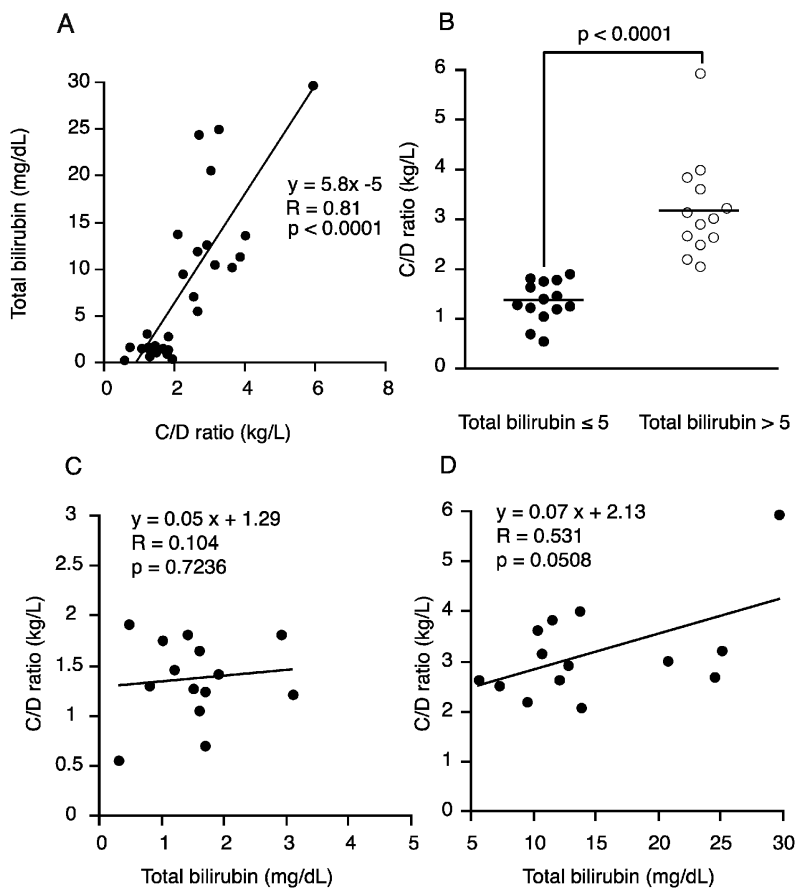

Fig. 3. The Relationship between the C/D Ratio of MCFG and Total Bilirubin Levels in the LDLT-recipients

A: Correlation between $\mathrm{C} / \mathrm{D}$ ratios and total bilirubin levels $(N=19, n$ $=28)$. B: Comparison of C/D ratios between patients with total bilirubin levels $\leq 5 \mathrm{mg} / \mathrm{dL}(N=9, n=14)$ and those with $>5 \mathrm{mg} / \mathrm{dL}(N=10, n=$ 14). C: Correlation between $\mathrm{C} / \mathrm{D}$ ratios and total bilirubin levels $\leq 5 \mathrm{mg} / \mathrm{dL}$ $(N=10, n=14)$. D: Correlation between $\mathrm{C} / \mathrm{D}$ ratios and total bilirubin levels $>5 \mathrm{mg} / \mathrm{dL}(N=9, n=14) . N=$ number of patients, $n=$ number of cases. Patients with no available bilirubin levels at the time of administration were excluded. The details are in ref. 30).

れた [Figs. 3(B) and (D)]。一方, $5 \mathrm{mg} / \mathrm{dL}$ 以下 の群では相関は認められなかった [Fig. 3(C)].ミ カファンギンは肝代謝酵素のサルファターゼやチト クロム P450 による影響を受けず, ${ }^{32,37)}$ ラットにお いて多剤耐性関連タンパク質 $2(\mathrm{ABCC} 2 / \mathrm{Mrp} 2)$ を
介して主に胆汁排泄されることが明らかにされてい る. ${ }^{38)} \mathrm{Mrp} 2$ は生体においてビリルビンの胆汁排泄 に関与するタンパクであり, ${ }^{39)}$ 肝機能障害の悪化に より重度の高ビリルビン血症を呈した患者ではミカ ファンギンの MRP2 を介した胆汁排泄が減少する ことが推察された。したがって，高ビリルビン血症 患者において高用量のミカファンギンを継続して使 用する場合は蓄積に伴う副作用の発症に注意が必要 と考えられる.

\section{6. おわりに}

わが国では米国で既に施行されている感染症やが んなどの専門薬剂師制度や薬剂師レジデント制度が 導入され，より臨床に即したシステムが構築されつ つある。一方，米国では臟器移植専門薬剂師の認定 制度が American Society of Health-System Pharmacists（ASHP）により認められ，United Network of Organ Sharing (UNOS) 規則や Centers for Medicare and Medicaid Services（CMS）認定基準におい ても学際的な移植チームで専門薬剤師の必要性を謳 つている. ${ }^{40)}$ わが国との医療制度の違いはあるが, 今後薬剂師に求められる薬物療法の専門家としての 役割はますます高まるものと予想される.さらに, 移植医療における治療の失敗は患者の死だけでな $<$, 膨大な医療資源の投入や, ドナーの臓器提供の 上に成り立っている．本研究成果は，日常臨床の投 与設計に応用可能なだけでなく，生体肝移植という 特殊な病態時の薬物体内動態の変動を明らかにする 上でも重要な知見であり，より安全で質の高い医療 を提供できるものと考えている．今後においても， 臨床薬剤師が薬剤の有効性を高める使用法の追求や 
副作用の事前回避あるいは早期発見，医療機関で実 施した取組みの評価に努めることは，医療の質向上 及び薬剂師の職能向上を達成するために重要である.

\section{謝辞研究の遂行にあたり，終始御懇篤なる御} 指導，御鞭撻を賜りました三重大学医学部附属病院 薬剂部 奥田真弘教授, 静岡県立大学薬学部臨床薬 剂学 賀川義之教授, 三重大学 小島康生名誉教授, 三重大学医学部附属病院薬剤部 岩本卓也准教授, 三重大学医学部附属病院肝胆膵移植外科 伊佐地秀 司教授， 臼井正信講師並びに水野修吾講師に襄心よ り深甚なる敬意を表します。また，研究に協力頂き ました共同研究者にこの場をお借りして深く感謝い たします。

\section{REFERENCES}

1) Denton M. D., Magee C. C., Sayegh M. H., Lancet, 353, 1083-1091 (1999) .

2) Hashida T., Masuda S., Uemoto S., Saito H., Tanaka K., Inui K., Clin. Pharmacol. Ther., 69, 308-316 (2001).

3) Kuehl P., Zhang J., Lin Y., Lamba J., Assem M., Schuetz J., Watkins P. B., Daly A., Wrighton S. A., Hall S. D., Maurel P., Relling M., Brimer C., Yasuda K., Venkataramanan R., Strom S., Thummel K., Boguski M. S., Schuetz E., Nat. Genet., 27, 383-391 (2001).

4) Uesugi M., Masuda S., Katsura T., Oike F., Takada Y., Inui K., Pharmacogenet. Genomics, 16, 119-127 (2006).

5) Wei-lin W., Jing J., Shu-sen Z., Li-hua W., Ting-bo L., Song-feng Y., Sheng Y., Liver Transpl., 12, 775-780 (2006).

6) Yu S., Wu L., Jin J., Yan S., Jiang G., Xie H., Zheng S., Transplantation, 81, 46-51 (2006).

7) Macphee I. A., Fredericks S., Mohamed M., Moreton M., Carter N. D., Johnston A., Goldberg L., Holt D. W., Transplantation, 79, 499-502 (2005)

8) Hesselink D. A., van Schaik R. H., van der Heiden I. P., van der Werf M., Gregoor P. J., Lindemans J., Weimar W., van Gelder T., Clin. Pharmacol. Ther., 74, 245-254 (2003) .

9) Tsuchiya N., Satoh S., Tada H., Li Z., Ohyama C., Sato K., Suzuki T., Habuchi T., Kato
T., Transplantation, 78, 1182-1187 (2004) .

10) Haufroid V., Wallemacq P., VanKerckhove V., Elens L., De Meyer M., Eddour D. C., Malaise J., Lison D., Mourad M., Am. J. Transplant., 6, 2706-2713 (2006).

11) Thervet E., Loriot M. A., Barbier S., Buchler M., Ficheux M., Choukroun G., Toupance O., Touchard G., Alberti C., Le Pogamp P., Moulin B., Le Meur Y., Heng A. E., Subra J. F., Beaune P., Legendre C., Clin. Pharmacol. Ther., 87, 721-726 (2010).

12) Uesugi M., Masuda S., Katsura T., Oike F., Takada Y., Inui K., Pharmacogenet. Genomics, 16, 119-127 (2006).

13) Fukudo M., Yano I., Yoshimura A., Masuda S., Uesugi M., Hosohata K., Katsura T., Ogura Y., Oike F., Takada Y., Uemoto S., Inui K., Pharmacogenet. Genomics, 18, 413423 (2008).

14) Muraki Y., Usui M., Isaji S., Mizuno S., Nakatani K., Yamada T., Iwamoto T., Uemoto S., Nobori T., Okuda M., Ann. Transplant., 16, 55-62 (2011).

15) Buttgereit F., Burmester G. R., Brand M. D., Immunol. Today, 21, 192-199 (2000).

16) Kowalski R. J., Post D. R., Mannon R. B., Sebastian A., Wright H. I., Sigle G., Burdick J., Elmagd K. A., Zeevi A., Lopez-Cepero M., Daller J. A., Gritsch H. A., Reed E. F., Jonsson J., Hawkins D., Britz J. A., Transplantation, 82, 663-668 (2006) .

17) Mizuno S., Hamada T., Nakatani K., Kishiwada M., Usui M., Sakurai H., Tabata M., Sakamoto Y., Nishioka J., Muraki Y., Okuda M., Nobori T., Isaji S., J. Hepatobiliary Pancreat. Sci., 18, 226-232; discussion 232-234 (2011)

18) Kuypers D. R., de Jonge H., Naesens M., Lerut E., Verbeke K., Vanrenterghem Y., Clin. Pharmacol. Ther., 82, 711-725 (2007).

19) Fukudo M., Yano I., Yoshimura A., Masuda S., Uesugi M., Hosohata K., Katsura T., Ogura Y., Oike F., Takada Y., Uemoto S., Inui K., Pharmacogenet. Genomics, 18, 413423 (2008).

20) Shimomura M., Masuda S., Goto M., Katsura T., Kiuchi T., Ogura Y., Oike F., Takada Y., Uemoto S., Inui K., Drug Metab. Pharmacokinet., 23, 313-317 (2008). 
21) Kiuchi T., Tanaka K., Nihon Ishinkin Gakkai Zasshi, 42, 189-193 (2001).

22) Paya C. V., Clin. Infect. Dis., 16, 677-688 (1993).

23) Ostrosky-Zeichner L., Rex J. H., Pappas P. G., Hamill R. J., Larsen R. A., Horowitz H. W., Powderly W. G., Hyslop N., Kauffman C. A., Cleary J., Mangino J. E., Lee J., $A n$ timicrob. Agents Chemother., 47, 3149-3154 (2003).

24) Azuma J., Nakahara K., Kagayama A., Kajiho T., Kawamura A., Suematsu H., Mukai T., Jpn. J. Chemother., 50, 148-154 (2002).

25) Ikeda F., Wakai Y., Matsumoto S., Maki K., Watabe E., Tawara S., Goto T., Watanabe Y., Matsumoto F., Kuwahara S., Antimicrob. Agents Chemother., 44, 614-618 (2000).

26) Denning D. W., Lancet, 362, 1142-1151 (2003).

27) Shimoeda S., Ohta S., Kobayashi H., Yamato S., Sasaki M., Kawano K., Biol. Pharm. Bull., 29, 1886-1891 (2006).

28) Ouchi H., Fujita M., Ikegame S., Inoshima I., Harada E., Nakanishi Y., J. Infect. Chemother., 13, 258-262 (2007).

29) Ota Y., Tatsuno K., Okugawa S., Yanagimoto S., Kitazawa T., Fukushima A., Tsukada K., Koike K., J. Infect. Chemother., 13, 208-212 (2007) .

30) Muraki Y., Iwamoto T., Kagawa Y., Sakurai H., Usui M., Isaji S., Uemoto S., Okuda M., Biol. Pharm. Bull., 32, 750-754 (2009).

31) Kishino S., Ohno K., Shimamura T., Furukawatodo H., Clin. Transplant., 18, 676-680
(2004) .

32) Hebert M. F., Smith H. E., Marbury T. C., Swan S. K., Smith W. B., Townsend R. W., Buell D., Keirns J., Bekersky I., J. Clin. Pharmacol., 45, 1145-1152 (2005).

33) Kohno S., Masaoka T., Yamaguchi H., Mori T., Urabe A., Ito A., Niki Y., Ikemoto H., Scand. J. Infect. Dis., 36, 372-379 (2004).

34) Hebert M. F., Smith H. E., Marbury T. C., Swan S. K., Smith W. B., Townsend R. W., Buell D., Keirns J., Bekersky I., J. Clin. Pharmacol., 45, 1145-1152 (2005).

35) Tabata K., Katashima M., Kawamura A., Tanigawara Y., Sunagawa K., Biol. Pharm. Bull., 29, 1706-1711 (2006).

36) Shimoeda S., Ohta S., Kobayashi H., Saitou H., Kubota A., Yamato S., Shimada K., Sasaki M., Kawano K., Biol. Pharm. Bull., 28, 477-480 (2005).

37) Abe F., Ueyama J., Kawasumi N., Nadai M., Hayashi T., Kato M., Ohnishi M., Saito H., Takeyama N., Hasegawa T., Antimicrob. Agents Chemother., 52, 3454-3456 (2008).

38) Abe F., Ueyama J., Kimata A., Kato M., Hayashi T., Nadai M., Saito H., Takeyama N., Noguchi H., Hasegawa T., Life Sci., 83, 229-235 (2008).

39) Jedlitschky G., Leier I., Buchholz U., Hummel-Eisenbeiss J., Burchell B., Keppler D., Biochem. J., 327 (Pt 1), 305-310 (1997).

40) Alloway R. R., Dupuis R., Gabardi S., Kaiser T. E., Taber D. J., Tichy E. M., WeimertPilch N. A., Am. J. Transplant., 11, 15761583 (2011). 